\title{
Heterolytic CH Activation and Catalysis by an O-Donor Iridium-Hydroxo Complex
}

William J. Tenn, III, Kenneth J. H. Young, Jonas Oxgaard, Robert J. Nielsen, William A. Goddard, III, and Roy A. Periana*

Donald P. and Katherine B. Loker Hydrocarbon Research Institute and Department of Chemistry, University of Southern California, Los Angeles, CA 90089-1661, and Materials and Process Simulation Center, Beckman Institute (139-74) Division of Chemistry and Chemical Engineering, California Institute of Technology, Pasadena, California 91125.

General Considerations: All air and water sensitive procedures were carried out either in an MBraun inert atmosphere glove box (under nitrogen), or using standard Schlenk techniques under argon. All deuterated solvents (Cambridge Isotopes), and pyridine (Aldrich) were used as received. Methyl lithium (1.6 M solution in diethyl ether) was degassed and filled with argon prior to use. The methoxide complex from which 1 was prepared was synthesized as described in the literature. ${ }^{1} \mathrm{GC} / \mathrm{MS}$ analysis was performed on a Shimadzu GC-MS QP5000 (ver. 2) equipped with cross-linked methyl silicone gum capillary column (DB5) and a Gas-pro column. The retention times of the products were confirmed by comparison to authentic samples. NMR spectra were obtained on a Varian Mercury-400 spectrometer at room temperature. All chemical shifts are reported in units of ppm and referenced to the residual protonated solvent. All high-resolution mass spectra were obtained by UCLA Pasarow Mass Spectrometry Laboratory on either an ESI, or a MALDI-TOF mass spectrometer. Elemental Analysis was performed by Desert Analytics of Tucson, Arizona.

X-ray Crystallography. Diffraction data for 1 was collected at low temperature ( $T=128 \mathrm{~K})$ on a Bruker SMART APEX CCD diffractometer with graphite-monochromated Mo K $\alpha$ radiation $(\lambda=0.71073 \AA$ ). The cell parameters for the Ir complex were obtained from the least-squares refinement of the spots (from 60 collected frames) using the SMART program. A hemisphere of the crystal data was collected and the intensity data was processed using the Saint Plus program. All calculations for structure determination were carried out using the SHELXTL package (version 5.1). ${ }^{2}$ Initial atomic positions were located by direct methods using XS, and the structure was refined by least-squares methods using SHELX. Absorption corrections were applied by using SADABS. ${ }^{3}$ Calculated hydrogen positions were input and refined in a riding manner along with the attached carbons. 


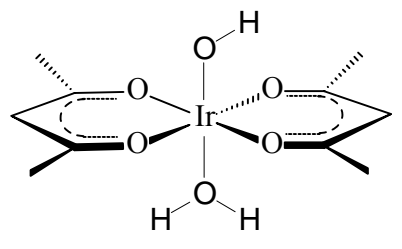

1. Synthesis of [HO-Ir(O,O-acac $\left.)_{\mathbf{2}}\left(\mathbf{H}_{\mathbf{2}} \mathbf{O}\right)\right]\left(\mathbf{1}-\mathbf{H}_{\mathbf{2}} \mathbf{O}\right)$ : A $30 \mathrm{~mL}$ re-sealable Schlenk tube was charged with the previously reported methoxide analog $\mathrm{CH}_{3} \mathrm{O}-\mathrm{Ir}(\mathrm{O}, \mathrm{O}-\mathrm{acac})_{2}\left(\mathrm{CH}_{3} \mathrm{OH}\right)$ $(55 \mathrm{mg}, 0.11 \mathrm{mmol})$ and water $(20 \mathrm{~mL})$ was added. The Schlenk tube was then sealed, and placed in a $60^{\circ} \mathrm{C}$ oil bath for $4 \mathrm{~h}$. The resulting yellow solution was cooled to room temperature, and the volatiles were removed in vacuo, yielding a yellow solid in quantitative yield. ${ }^{1} \mathrm{H}$ NMR $\left(\mathrm{D}_{2} \mathrm{O}\right): \delta 5.56(\mathrm{~s}, 2 \mathrm{H}, \mathrm{CH}), 1.89(\mathrm{~s}$, $\left.12 \mathrm{H}, \mathrm{CH}_{3}\right) .{ }^{13} \mathrm{C}\left\{{ }^{1} \mathrm{H}\right\}$ NMR $\left(\mathrm{D}_{2} \mathrm{O}\right): \delta 186.68(\mathrm{C}$-acac, $\mathrm{C}=\mathrm{O}), 102.40(\mathrm{O}-\mathrm{acac}, \mathrm{CH}), 25.60\left(\mathrm{O}\right.$-acac, $\left.\mathrm{CH}_{3}\right)$. HRMS (ESI): Calculated for $\mathrm{C}_{10} \mathrm{H}_{18} \mathrm{IrO}_{6}(\mathrm{M}+\mathrm{H})$ 427.0727, found 427.0712 .

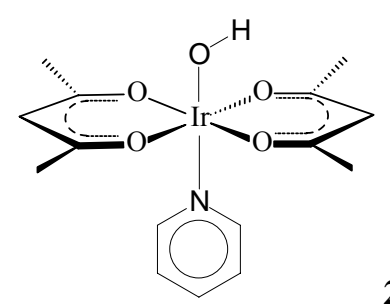

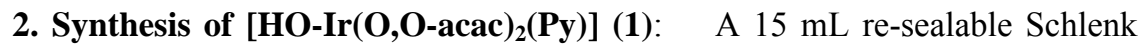
tube was charged with $\mathbf{1}-\mathbf{H}_{\mathbf{2}} \mathbf{O}(30 \mathrm{mg}, 0.11 \mathrm{mmol})$ and pyridine $(10 \mathrm{~mL})$ was added. The Schlenk tube was then sealed, and placed in a $60^{\circ} \mathrm{C}$ oil bath for $30 \mathrm{~min}$. The resulting dark-orange solution was cooled to room temperature, and the volatiles were removed in vacuo, yielding an orange solid in quantitative yield. The complex is hygroscopic. ${ }^{1} \mathrm{H}$ NMR $\left(\mathrm{CDCl}_{3}\right): \delta 8.32(\mathrm{~d}, 2 \mathrm{H}, \mathrm{o}-\mathrm{Py}), 7.79(\mathrm{t}, 1 \mathrm{H}, \mathrm{p}-\mathrm{Py}), 7.33(\mathrm{t}, 2 \mathrm{H}, \mathrm{m}-\mathrm{Py})$, 5.42(s, 2H, CH), 2.03(s, $\left.12 \mathrm{H}, \mathrm{CH}_{3}\right),-0.96\left(\mathrm{~s}, 1 \mathrm{H}, \mathrm{Ir}-\mathrm{OH}\right.$, at $\left.-500^{\circ} \mathrm{C}\right) .{ }^{13} \mathrm{C}\left\{{ }^{1} \mathrm{H}\right\} \mathrm{NMR}\left(\mathrm{CDCl}_{3}\right): \delta 185.6(\mathrm{C}$-acac, $\mathrm{C}=\mathrm{O}$ ), 152.1(o-Py), 137.4(p-Py), 125.2(m-Py), 102.7(O-acac, $\mathrm{CH}), 26.9\left(\mathrm{O}-\mathrm{acac}, \mathrm{CH}_{3}\right)$. HRMS (MALDITOF): Calculated for $\mathrm{C}_{13} \mathrm{H}_{20} \mathrm{IrNO}_{5} \mathrm{Na}(\mathrm{M}+\mathrm{Na})$ 510.0863, found 510.0876. Elemental Analysis: Calculated for $\mathrm{C}_{12} \mathrm{H}_{21} \mathrm{IrO}_{6}$ : C, 37.03; H, 4.14; N, 2.88. Found: C, 36.63; H, 4.17; N, 2.64. Single crystals were grown by slow evaporation of a concentrated sample in chloroform.

Crystal data for 1: a yellow-orange prism-shaped crystal of dimensions $0.24 \times 0.18 \times 0.10 \mathrm{~mm}^{3}$ was grown from chloroform by slow evaporation of the solvent. $\mathrm{C}_{16} \mathrm{H}_{21} \mathrm{Cl}_{3} \mathrm{IrNO}_{5}$ : monoclinic, group P2(1)/n, $a=7$. $7108(5) \AA, b=18.4718(12) \AA, c=14.8523(10) \AA, V=2111.8(2) \AA^{3}, Z=4, T=128(2) \mathrm{K}, D_{\text {calcd }}=1.906$ $\mathrm{Mg} / \mathrm{m}^{3}, R(F)=2.42$ for 12793 observed reflections. All non-hydrogen atoms were refined with anisotropic displacement parameters.

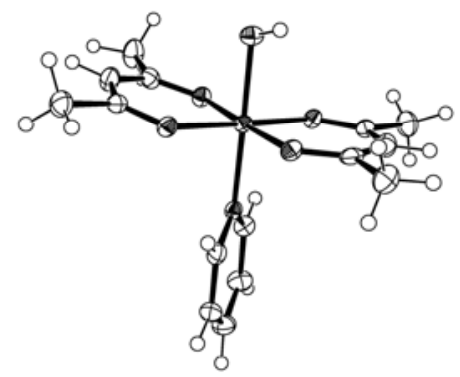


ORTEP diagram of complex 1, showing ellipsoids at the $50 \%$ probability level. A molecule of cocrystallized $\mathrm{CHCl}_{3}$ has been omitted for clarity. Selected bond distances (Á): Ir1-O5, 2.018(4); Ir1-N1, 2.044(5).

Reaction between 1 and benzene: To a re-sealable Schlenk tube was added 1 ( $5 \mathrm{mg}, 0.01 \mathrm{mmol})$, and benzene $(1 \mathrm{~mL})$. The resulting suspension was thoroughly degassed before being placed under an atmosphere of argon. The tube was sealed and then heated to $180^{\circ} \mathrm{C}$ in an oil bath for $10 \mathrm{~h}$. After a few minutes of heating, the solid dissolved to yield a clear orange-yellow solution that lightened over the course of the reaction to clear light yellow. After cooling to room temperature, the solvent was removed to yield a yellow solid which was characterized as the iridium phenyl complex which has been previously reported by our group. ${ }^{4 a}$ Pure 2 was isolated by preparative TLC (alumina, 1000 microns, Analtech, Inc.) using $\mathrm{CHCl}_{3}$ as the elutant. ${ }^{1} \mathrm{H}$ NMR (THF-d8): $\delta 6.65(\mathrm{~m}, 3 \mathrm{H}, \mathrm{Ph}), 6.57(\mathrm{~m}, 2 \mathrm{H}, \mathrm{Ph}), 5.21(\mathrm{~s}, 2 \mathrm{H}, \mathrm{CH}), 1.77(\mathrm{~s}, 12 \mathrm{H}$, $\left.\mathrm{CH}_{3}\right),{ }^{13} \mathrm{C}\{1 \mathrm{H}\}$ NMR (THF-d 8 ): $\delta 184.5(\mathrm{~s}, \mathrm{O}$-acac, C=O), 136.3(s, Ph), 125.3(s, Ph), 122.9(s, Ph), 103.0(s, $\mathrm{O}$-acac, $\mathrm{CH}), 26.6\left(\mathrm{~s}, \mathrm{O}\right.$-acac, $\mathrm{CH}_{3}$ ). Further treatment of this material with pyridine yielded the pyridyl derivative, which has been previously reported by our group. ${ }^{1} \mathrm{H} \mathrm{NMR}\left(\mathrm{CDCl}_{3}\right): \delta 8.52(\mathrm{~m}, 2 \mathrm{H}$, py), 7.81(m, 1H, py), 7.46(m, 2H, py), 6.99(m, 5H, Ph), 5.14(s, 2H, CH), 1.80(s, 12H, $\left.\mathrm{CH}_{3}\right),{ }^{13} \mathrm{C}\{1 \mathrm{H}\} \mathrm{NMR}$ $\left(\right.$ THF-d $\left._{8}\right): \delta 184.5(\mathrm{~s}, O$-acac, C=O), 149.7(s, py), 137.3(s, Ph), 135.7(s, py), 131.3(s, Ph), 125.2(s, py), 124.5(s, Ph), 103.2(s, O-acac, CH), 27.2(s, $\mathrm{O}$-acac, $\left.\mathrm{CH}_{3}\right)$. MS (ESI): Calculated for $\mathrm{C}_{21} \mathrm{H}_{25} \mathrm{IrNO}_{4}(\mathrm{M}+\mathrm{H})$ 548.14 , found 548.20 .

Reaction between 1 and toluene: To an NMR tube fitted with a re-sealable, Teflon J-Young valve was added $1(5 \mathrm{mg}, 0.01 \mathrm{mmol})$, and toluene $(0.5 \mathrm{~mL})$. The resulting suspension was thoroughly degassed before being placed under an atmosphere of argon. The tube was sealed and then heated to $180^{\circ} \mathrm{C}$ in an oil bath for $10 \mathrm{~h}$. After a few minutes of heating, the solid dissolved to yield a clear orange-yellow solution that lightened over the course of the reaction to clear light yellow. After cooling to room temperature, the solvent was removed to yield a yellow solid which was characterized as the iridium toluyl complex. ${ }^{1} \mathrm{H}$ NMR $\left(\mathrm{CDCl}_{3}\right): \delta 8.56(\mathrm{~m}, 2 \mathrm{H}$, o-py), 7.87(m, 1H, m-py), 7.45(m, 2H, p-py), 6.90(m, 4H, Ph), 5.16(s, 2H, $\mathrm{CH}), 2.38(\mathrm{~s}, 1 \mathrm{H}$, para- $\mathrm{CH}), 2.28(\mathrm{~s}, 2 \mathrm{H}, \mathrm{m}-\mathrm{CHs}), 1.73\left(\mathrm{~s}, 12 \mathrm{H}, \mathrm{CH}_{3}\right)$.

\section{H/D exchange:}

Analysis: Catalytic H-D exchange reactions were quantified by monitoring the increase of deuterium into $\mathrm{C}_{6} \mathrm{H}_{6}$ by GC/MS analyses. This was achieved by deconvoluting the mass fragmentation pattern obtained from the MS analysis, using a program developed with Microsoft EXCEL. An important assumption made with this method is that there are no isotope effects on the fragmentation pattern for the various benzene isotopomers. Fortunately, because the parent ion of benzene is relatively stable towards fragmentation, it can be used reliably to quantify the exchange reactions. The mass range from 78 to 84 (for benzene) was 
examined for each reaction and compared to a control reaction where no metal catalyst was added. The program was calibrated with known mixtures of benzene isotopomers. The results obtained by this method are reliable to within 5\%. Thus, analysis of a mixture of $\mathrm{C}_{6} \mathrm{H}_{6}, \mathrm{C}_{6} \mathrm{D}_{6}$ and $\mathrm{C}_{6} \mathrm{H}_{5} \mathrm{D}_{1}$ prepared in a molar ratio of 40: 50: 10 resulted in a calculated ratio of $41.2\left(\mathrm{C}_{6} \mathrm{H}_{6}\right): 47.5\left(\mathrm{C}_{6} \mathrm{D}_{6}\right): 9.9\left(\mathrm{C}_{6} \mathrm{H}_{5} \mathrm{D}_{1}\right)$. Catalytic $\mathrm{H} / \mathrm{D}$ exchange reactions were thus run for sufficient reaction times to be able to detect changes $>5 \%$ exchange. 2 was the catalyst used to carry out the H/D exchange between benzene and deuterium oxide.

In a typical experiment, a $5 \mathrm{~mL}$ Schlenk tube was charged with $10 \mathrm{mg}$ of 1 , benzene $1 \mathrm{~mL}$, and $1 \mathrm{~mL}$ of deuterium oxide under an atmosphere of argon. The tube was then placed in a temperature controlled oilbath maintained at $190{ }^{\circ} \mathrm{C}$, and deuterium incorporation was then measured as described above. A representative graph of the data from this reaction is shown below.

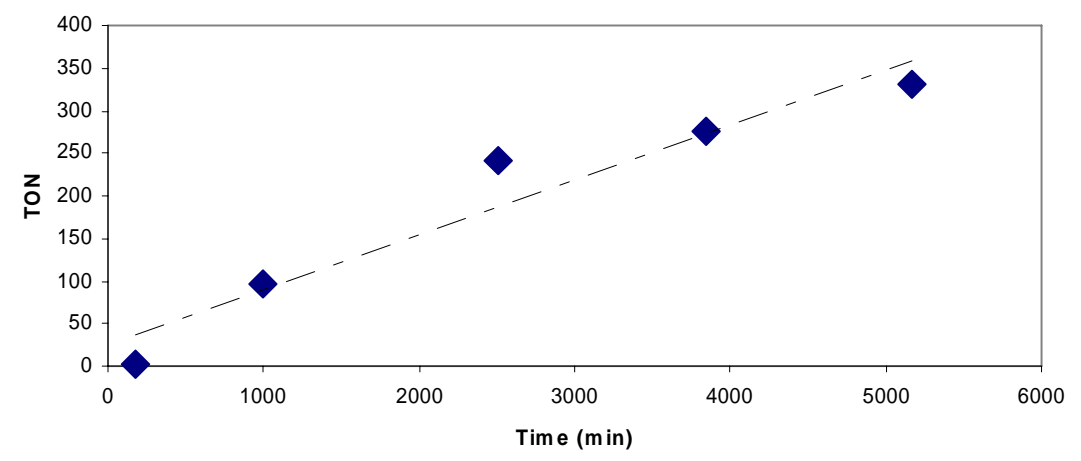

Plot of TON vs. Time for Benzene/ $\mathrm{D}_{2} \mathrm{O}$ H/D Exchange with 1.

Dependence of $\mathbf{H} / \mathbf{D}$ exchange rate on pyridine concentration: A stock solution of $\mathbf{1}(10 \mathrm{mM})$ in $1 \mathrm{~mL}$ $\mathrm{C}_{6} \mathrm{H}_{6}$ and $1 \mathrm{~mL} \mathrm{D}_{2} \mathrm{O}$ was added to $5 \mathrm{~mL}$ thick-walled ampoules equipped with high-vacuum valves. Pyridine was added ( 0.5 to 2 molar equivalents) and the ampoule was heated in a well-stirred oil bath maintained at $190^{\circ} \mathrm{C}$. The mixtures were then sampled at regular intervals and the extent of deuterium incorporation was determined as described above. A graph of this data is shown below. 


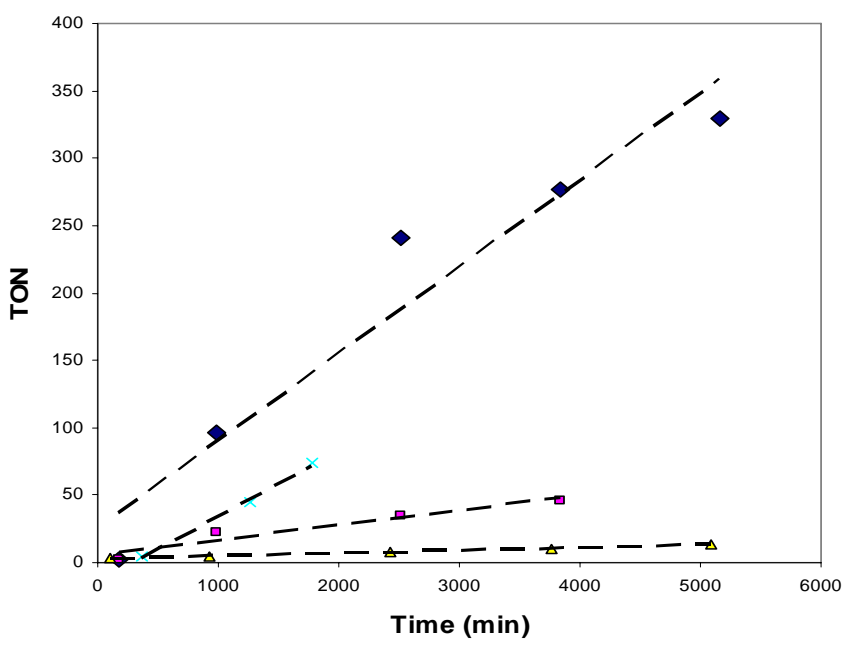

Plots of TON vs. Time for Benzene/D2O H/D Exchange with $\mathbf{1}$ for runs with varied free pyridine added. Where $\diamond=0$ Py added, $\mathrm{x}=0.5 \mathrm{~mol}$ eq, $\boldsymbol{\square}=1 \mathrm{~mol}$ eq, and $\boldsymbol{\Delta}=2 \mathrm{~mol}$ eq.

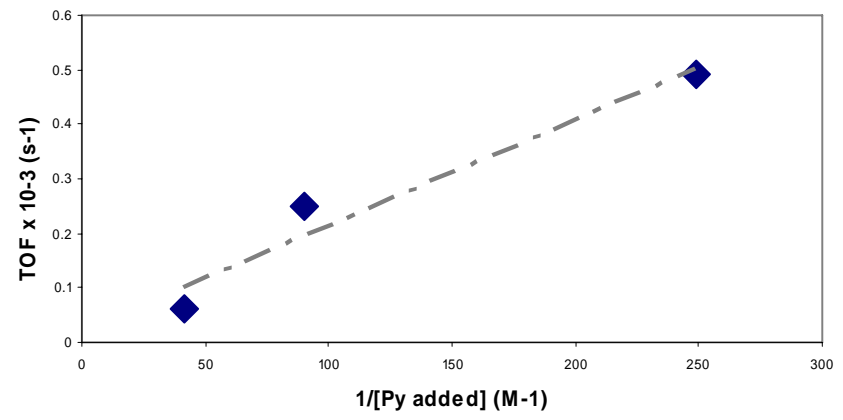

Plot of TOF vs. 1/[Py] for Benzene/D2O H/D Exchange with 1.

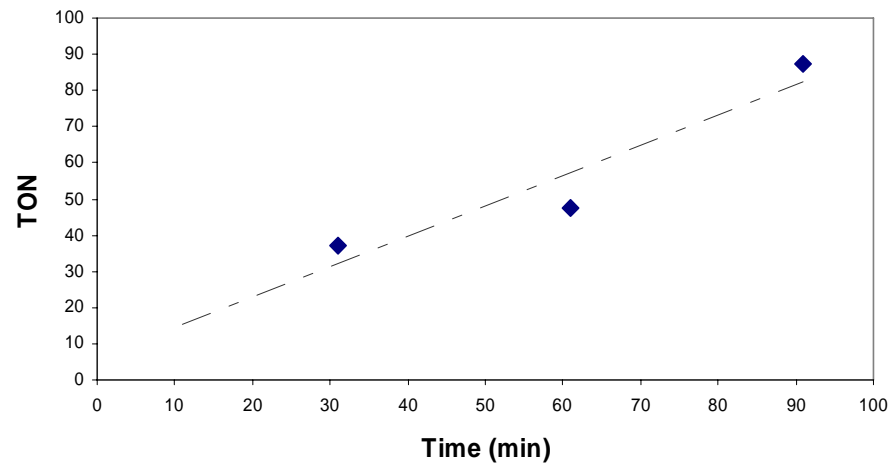

Plot of TON vs. Time for Benzene/D2O H/D Exchange with 1-H2 $\mathbf{O}$. 
Deuterium kinetic isotope effect on benzene $\mathbf{C H}$ activation by 1: Three $5 \mathrm{~mL}$ Schlenk tubes were charged with $10 \mathrm{mg}$ of $\mathbf{1}$, and $0.5 \mathrm{~mL}$ of a $1: 1$ molar mixture of $\mathrm{C}_{6} \mathrm{H}_{6} / \mathrm{C}_{6} \mathrm{D}_{6}$, or 1,3,5-trideuterobenzene under an atmosphere of argon. The tubes were then placed in a temperature controlled oil-bath maintained at $180{ }^{\circ} \mathrm{C}$ until the reaction had reached $10 \%$ completion. The tubes were then cooled and methyl lithium was added. The gas phase was then analyzed via GCMS. The molar ratio of the liberated methane isotopomers was determined using a deconvolution spreadsheet calibrated with known mixtures of methane isotopomers. The liquid phase was analyzed to ensure that deuterium scrambling was minimized in the starting materials. Control experiments without added 1, and with $\mathbf{1}$ but without heating were also carriedout, each in triplicate, to account for background generation of methane from reactions with methyl lithium.
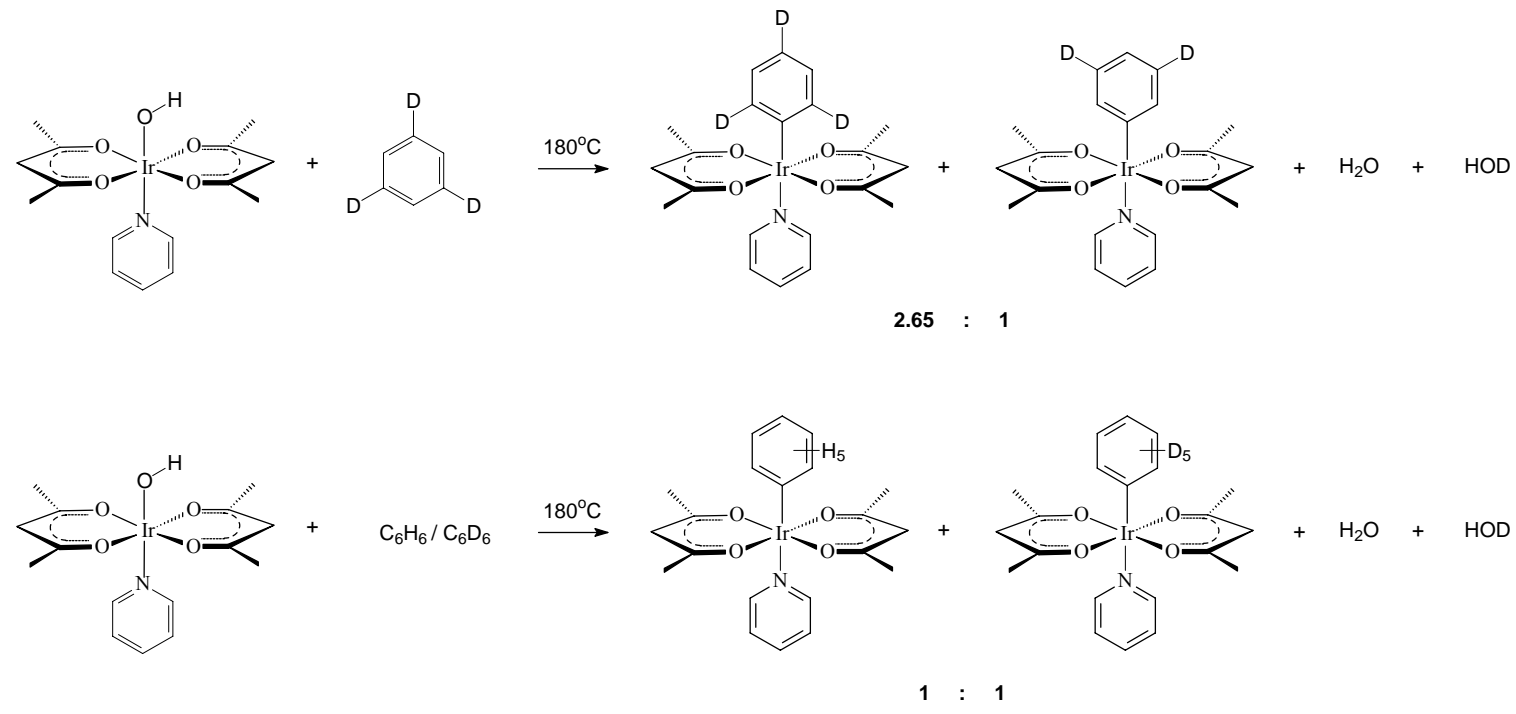

Theoretical Calculations: All calculations were performed using the hybrid DFT functional B3LYP as implemented by the Jaguar 6.0 and Jaguar 6.5 program packages. ${ }^{4}$ This DFT functional utilizes the Becke three-parameter functional ${ }^{5}$ (B3) combined with the correlation functional of Lee, Yang, and $\operatorname{Par}^{6}$ (LYP), and is known to produce good descriptions of reaction profiles for transition metal containing compounds. ${ }^{7,8}$ The metals were described by the Wadt and Hay ${ }^{9}$ core-valence (relativistic) effective core potential (treating the valence electrons explicitly) using the LACVP basis set with the valence double- $\mathcal{F}$ contraction of the basis functions, LACVP**. All electrons were used for all other elements using a modified variant of Pople's ${ }^{10} 6-31 \mathrm{G}^{* *}$ basis set, where the six $\mathrm{d}$ functions have been reduced to five.

Implicit solvent effects of the experimental benzene medium were calculated with the Poisson-Boltzmann (PBF) continuum approximation, ${ }^{11}$ using the parameters $\varepsilon=2.284$ and $\mathrm{r}_{\text {solv }}=2.602 \AA$. Due to the increased cost of optimizing systems in the solvated phase (increase in computation time by a factor of $\sim 4$ ) solvation effects are calculated here as single point solvation corrections to gas phase geometries. Our previous work on the $\operatorname{Ir}(\mathrm{acac})_{2}$ system has shown that the total energies, geometries, frequencies and zero point energies were also largely unchanged when the systems were optimized in the solvation phase. 
All energies here are reported as $\Delta \mathrm{E}+$ zero point energy corrections at $0 \mathrm{~K}+$ solvation correction. Relative energies on the $\Delta \mathrm{H}(0 \mathrm{~K})$ surface are expected to be accurate to within $3 \mathrm{kcal} / \mathrm{mol}$ for stable intermediates, and within $5 \mathrm{kcal} / \mathrm{mol}$ for transition structures. Moreover, relative energies of iso-electronic species (such as regio-isomers) are considerably more accurate, since the errors largely cancel.

Free energies are not included, due to the inadequacies of free energy calculations in solutions. However, a free energy term is implicitly included in the PBF solvation methodology.

All geometries were optimized and evaluated for the correct number of imaginary frequencies through vibrational frequency calculations using the analytic Hessian. Zero imaginary frequencies correspond to a local minimum, while one imaginary frequency corresponds to a transition structure.

To reduce computational time the methyl groups on the acac ligands were replaced with hydrogens. Control calculations show that relative energies of intermediates and transition structures change less than $0.1 \mathrm{kcal} / \mathrm{mol}$ when methyl groups are included.

The deuterium kinetic isotope effect calculated for the reaction of 1,3,5-trideuterobenzene with (acac$\mathrm{O}, \mathrm{O})_{2} \operatorname{Ir}(\mathrm{III})(\mathrm{OH})(\mathrm{Py})$ assumes that generation of $\mathrm{HOH}$ and HOD involve the same intermediates up until the arene complex (acac-O,O $)_{2} \operatorname{Ir}(\mathrm{III})(\mathrm{OH})\left(\mathrm{C}_{6} \mathrm{H}_{3} \mathrm{D}_{3}\right)$ (below, 1). Using transition state theory, the kinetic isotope effect is then

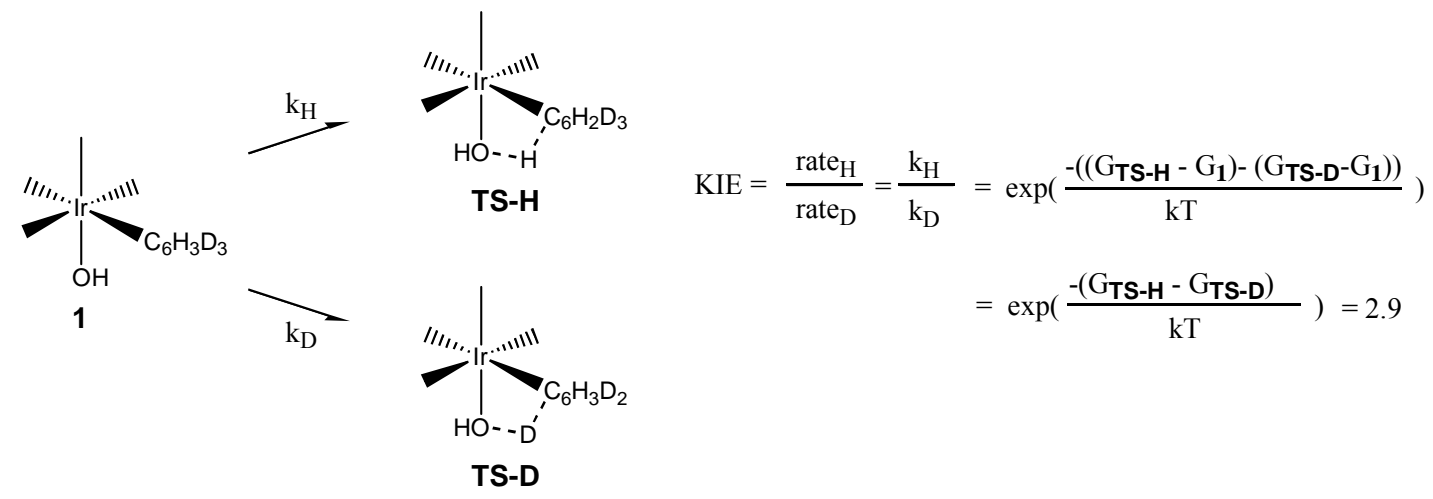

where $G_{\text {TS-H }}$ and $G_{\text {TS-D }}$ contain the mass dependent quantities (zero point energy and vibrational enthalpy and entropy at 473K) evaluated using the appropriately mass-weighted Hessians.

(1) Tenn, W. J., III; Young, K. J. H.; Bhalla, G.; Oxgaard, J.; Goddard, W. A., III; Periana, R. A. J. Am. Chem. Soc. 2005, 127, 14173.

(2) Sheldrick, G. M. SHELXTL, version5.1; Bruker Analytical X-ray System, Inc.: Madison, WI, 1997.

(3) Blessing, R. H. Acta Crystallogr. 1995, A51, 33-38.

(4) Jaguar 6.0, Schrodinger, Inc., Portland, Oregon, 2004, Jaguar 6.5, Schrodinger, Inc., Portland, Oregon, 2005.

(5) Becke, A. D. J. Chem. Phys. 1993, 98, 5648.

(6) Lee, C.; Yang, W.; Parr, R. G. Phys. Rev. B 1988, 37, 785.

(7) Baker, J.; Muir, M.; Andzelm, J.; Scheiner, A. In Chemical Applications of Density-Functional Theory; Laird, B. B., Ross, R. B., Ziegler, T., Eds.; ACS Symposium Series 629; American Chemical Society: Washington, DC, 1996. 
(8) Niu, S.; Hall, B. M. Chem. Rev. 2000, 100, 353.

(9) (a) Hay, P. J.; Wadt, W. R. J. Chem. Phys. 1985, 82, 299. b) Goddard, W. A., III Phys. Rev. 1968, 174, 659. (b) Melius, C. F.; Olafson, B. O.; Goddard, W. A., III Chem. Phys. Lett. 1974, $28,457$.

(10) (a) Hariharan, P. C.; Pople, J. A. Chem. Phys. Lett. 1972, 16, 217. (b) Francl, M. M.; Pietro, W. J.; Hehre, W. J.; Binkley, J. S.; Gordon, M. S.; DeFrees, D. J.; Pople, J. A. J. Chem. Phys. 1982, 77, 3654.

(11) (a) Tannor, D. J.; Marten, B.; Murphy, R.; Friesner, R. A.; Sitkoff, D.; Nicholls, A.; Ringnalda, M.; Goddard, W. A., III; Honig, B. J. Am. Chem. Soc. 1994, 116, 11875. (b) Marten, B.; Kim, K.; Cortis, C.; Friesner, R. A.; Murphy, R. B.; Ringnalda, M. N.; Sitkoff, D.; Honig, B. J. Phys. Chem. 1996, 100, 11775 . 